\title{
Kontruksi Kerjasama LSM dan Pemerintah Dalam Pembangunan Daerah Perspektif Undnag-undang Keormasan
}

\author{
Yusdiyanto
}

Dosen Bagian Hukum Tata Negara Fakultas Hukum Universitas Lampung

\begin{abstract}
Abstrak
Sesuai Instruksi Menteri Dalam Negeri No. 8 tahun 1990 tentang pembinaan Lembaga Swadaya Masyarakat. LSM adalah salah satu wadah warga, rakyat, masyarakat untuk berekspresi, mengapresiasikan pikirannya ditengah masyarakat dan Negara. Melalui wadah tersebut mereka bebas mengemukakan visi dan misinya, hati nuraninya, melampiaskan uneg-uneg serta secara sadar memperjuangkan hak-hak sipil menurut peraturan perundang-undangan yang berlaku. UUD 1945 memberikan garansi akan keberadaan LSM di Indonesia sebagaimana Pasal 28E: "Setiap warganegara diberikan kebebasan beragama, meyakini kepercayaan, memilih kewarganegaraan, memilih tempat tinggal, kebebasan berserikat, berkumpul dan berpendapat". Di era otonomi daerah keberadaan LSM sangat penting dan berguna dalam rangka memanfaatkan ruang partisipasi masyarakat, perencanaan dari bawah dan kemitraan, anggaran yang pro-poor dan peka jender serta tata kelola pemerintahan yang baik menjadi prinsip-prinsip utama yang mempengaruhi warna pembangunan daerah.
\end{abstract}

Kata Kunci: LSM, Pemerintah, dan Warganegara

\section{Pendahuluan}

Keberadaan Lembaga swadaya masyarakat (LSM) atau sering disebut dengan nama lain Non Government Organization (NGO) atau organisasi non pemerintah (Ornop), yang dewasa ini sangat mewarnai perkembangan politikhukum ketatanegaraan di Indonesia. Sejak di dirikan republik ini sampai sekarang, LSM selalu ambil peran dalam banyak hal di kehidupan berbangsa dan bernegara seperti bidang hukum, politik, agama, ekonomi, sosial kemasyarakatan, lingkungan dsb. Lihat saja di bidang hukum, konflik antara KPK versus Kapolri, LSM ikut serta berperan menekan pemerintah sebagai pemegang otoritas yang berakhir pada Presiden angkat bicara dengan memberikan beberapa resolusi penyelesaian konflik kedua lembaga dalam hal penangan kasus korupsi.

Keberadaan LSM di mata hokum sangat diakui legalitasnya, lihat saja UUD Undang-Undang Dasar secara langsung memberikan pengakuan hukum sesuai Pasal 28E: "Setiap warganegara diberikan kebebasan beragama, meyakini kepercayaan, memilih kewarganegaraan, memilih tempat tinggal, kebebasan berserikat, berkumpul dan berpendapat". Artinya pasal ini memberikan arah bahwa setiap warganegara siberikan hak untuk berserikat, berkumpul dan berpendapat sepanjang tidak 
bertentangan dengan peraturan perundang-udangan yang berlaku. Perlindungan konstitusi tersebut membuat keberadaan LSM sampai saat ini menjadi semakin meningkat dibanding periode yang lalu, menurut data yang tercatat di Kementrian Dalam Negeri tahun 2002 jumlah LSM sekitar 13.500 LSM. $^{1}$ Data tersebut menunjukkan dengan semangat demokratisasi yang ada, LSM sebagai wadah warga negara berpartisipasi dalam penyelenggaraan pemerintahan di semua unsur pemerintahan.

Disamping perlindungan konstitusi dan undang-undang, meningkatnya jumlah LSM tidak terlepas dari permasalahan yang menimpa republic ini, mulai pada level perumus, pembahasan, penetapan sampai pada realisasi kebijakan dari penyelenggara pemerintahan sangat buruk dan selalui mendapat sorotan publik, hal itu lah yang memotivasi beberapa kelompok masyarakat yang mempunyai keahlian tertentu untuk membuat sebuah organisasi yang dikelola secara swadaya, yang akhirnya dikenal dengan nama lembaga swadaya masyarakat.

Pada fase perkembangannya saat rezim reformasi kini LSM selalu berperan aktif dalam roda pembangunan dan terasa gaung vokalnya bersuara ketika terjadi permasalahan pada level penyelenggaraan Negara baik di bidang yudikatif (penegakan dan penangan hukum lemah), eksekutif (pemerintah cendrung tidak sensitive atas penderitaan rakyat) dan

${ }^{1}$ Kompas 13 Januari 2003 dalam NGO ditengah Kepungan Kepentingan Global,

http://lafadl.wordpress.com/2006/07/15/ng o-di-tengah-kepungan-kepentingan-global/. legislative (pembuatan hokum yang refresif). Terlepas dari perihal tersebut, prasyarat sebuat negara demokrasi menempatkan LSM sebagai salah-satu pilar demokrasi dalam kaitan partisapasi masyarakat. Terutama berkaitan masalah-masalah publik, contohnya: jadwal pigub, kebijakan public, kerusakan lingkungan, perambahan hutan, HAM, perilaku korupsi Kepala Daerah/Pejabat Publik, penyalahgunaan anggaran daerah, pedidikan, kesehatan, bencana alam, kemiskinan, kelaparan, dan lain-lain.

Berbagai polemik tersebut, LSM-lah yang selama ini sangat ngotot dan aktif menyuarakan keluhan masyarakat ke tingkat Legislastif (DPRD), Eksekutif dan Yudikatif. Bila tidak minimal permasalahan Warga Negara disampaikan kemedia dan akhirnya menjadi perhatian Publik.

Permasalahan yang kerap muncul menempatkan keberadaan LSM sering berhadapan dengan pemerintah, beberapa pejabat pemerintahan menyebut LSM sebagai kawan di satu kesempatan tapi juga menjadi lawan di forum lainnya. Disinilah peran LSM yang berbeda atau tidak dapat disamakan dengan lembaga konsultan yang bekerja hanya berdasarkan kontrak. Ada nilai-nilai dan semangat LSM yang tidak dapat digantikan yaitu tanggung jawab moral dan passion.

Orientasi visi-misi sebagian lembaga LSM adalah memperjuangkan keadilan social (social justice) bagi masyarakat terutama kelompok masyarakat yang terpinggirkan. Pendampingan dan advokasi terus dilakukan dengan tujuan untuk membuat perubahan sistemik dalam arus utama pembangunan dan menunjukkan 
keberpihakkan khususnya pada kelompok masyarakat yang ditelantarkan atau rakyat pada umumnya.

Atas pentingnya keberadaan LSM, maka penulis mengangkat permasalahan mengenai bagaimana kerjasama LSM dan pemerintah dalam melaksanakan pembangunan daerah berdasarkan Undang-Undang No. 8 Tahun 1985 tentang Organisasi Masyarakat.

\section{Pembahasan}

Secara filosofis pengertian LSM secara tegas terdapat dalam Instruksi Menteri Dalam Negeri No. 8/1990, tentang Pembinaan Lembaga Swadaya Masyarakat. Menyebutkan bahwa LSM adalah organisasi/lembaga yang anggotanya adalah masyarakat warganegara Republik Indonesia yang secara sukarela atau kehendak sendiri berniat serta bergerak di bidang kegiatan tertentu yang ditetapkan oleh organisasi/lembaga sebagai wujud partisipasi masyarakat dalam upaya meningkatkan taraf hidup dan kesejahteraan masyarakat, yang menitikberatkan kepada pengabdian secara swadaya.

\section{Generasi LSM di Indonesia}

Menurut David Korten (1987)
LSM di Indonesia dapat
dikelompokkan menjadi 3 (tiga)
generasi, yaitu: generasi bantuan dan
kesejahteraan, generasi keswadayaan
dalam skala lokal dan generasi
pembangunan yang berkelanjutan.

1. Generasi pertama, peran LSM memberikan bantuan dalam penanganan kelaparan akibat banjir, akibat perang, dipengungsian dan bencana alam lainnya, seperti: distribusi pangan, penyediaan tempat penampungan dan pengiriman tim kesehatan. Seperti Palang Merah Indonesia (PMI).

2. Generasi kedua, Peran LSM muncul akibat reaksi atas keterbatasan bantuan kesejahteraan sebagai strategi pembangunan. Pada generasi ini peran LSM dengan melakukan pengembangan masyarakat dengan penekanan pada swadaya lokal, seperti: memperbaiki cara-cara bertani, memperbaiki infrastruktur lokal, pelayanan kesehatan yang bersifat pencegahan, seperti yang dilakukan oleh Pemerintah, namun difokuskan pada wilayahwilayah yang tidak terjangkau atau tidak memadainya layanan pemerintah.

3. Generasi ketiga, LSM mengembangkan alternatifalternatif baru yang berbeda dengan pemerintah, namun mendukung modernisasi dan developmentalis yang merupakan idiologi kapitalis yang selama ini dianut oleh pemerintah. Artinya seiring perjalanan rezim Negara, LSM ambil bagian dengan mengerjakan apa yang tidak dikerjakan oleh pemerintah, tetapi bermitra dengan pemerintah.

Dari hasil pengamatan dapat diketahui, keberadaan LSM di Indonesia dapat digolongkan menjadi 3 (tiga) tipologi, yaitu: Konformisme, Reformis dan Transformatif.

1. Tipe Konformisme adalah aktivis LSM melakukan pekerjaan dengan didasarkan pada paradigma karitatif, dengan motivasi menolong rakyat yang 
didasarkan pada niat baik untuk membantu yang membutuhkan.

2. Tipe Reformis adalah pemikiran yang didasarkan pada ideology developmentalisme dan modernisasi yang akhirnya masyarakat miskin karena mereka tidak berpendidikan dan tidak memiliki modal. Karena itu kemudian LSM menfasilitasi melalui pelatihan-pelatihan dan memberi bantuan modal untuk berusaha.

3. Tipe Transformatif adalah LSM berusaha mengubah struktur dan superstruktur yang menindas rakyat dan membuka kemungkinan bagi rakyat untuk mewujudkan kesejahteraan rakyat. Tipe ini lebih pada melihat dan mencari struktur dan superstruktur yang memungkinkan bagi rakyat untuk mengontrol perubahan social menuju jalan demokratis dalam pergeseran social, hokum, ekonomi dan politik.

\section{Partisipasi LSM dalam Pembangunan}

Persoalan mendasar dari kehidupan bernegara dalam proses penyelenggaran pemerintah baik di tingkat pusat maupun daerah adalah bagaimana membangun atau menciptakan mekanisme pemerintahan yang dapat mengemban visi-misi untuk mewujudkan raison de'etre pemerintahan yaitu mensejahterakan masyarakat secara berkeadilan.

Besarnya kewenangan yang dimiliki daerah tentu akan mendatangkan manfaat yang besar bagi masyarakat apabila pemerintah daerah mampu membangun demokrasi ditingkat lokal (local level democracy) melalui peningkatan partisipasi publik. $^{2}$ Ringkasnya partisipasi publik dapat mewujudkan tiga elemen penting yang harus dicapai yaitu demokrasi, partisipasi dan akuntabilitas. ${ }^{3}$

Partisipasi masyarakat merupakan bagian penting dalam proses demokratisasi yang tengah berjalan, tidak hanya sebagai pengejawantahan dari asas keterbukaan yang melandasi sebuah negara demokratis, tetapi juga merupakan perwujudan dari perlindungan hak asasi masyarakat untuk ikut aktif dalam pemerintahan. Sri Soemantri M., mengatakan ide demokrasi menjelmakan dirinya dalam lima hal, dua diantaranya adalah pemerintah harus bersikap terbuka (openbaarheid van bestur) dan dimungkinkannya rakyat yang berkepentingan menyampaikan keluhannya mengenai tindakantindakan pejabat yang dianggab merugikan. ${ }^{4}$ Philipus M. Hadjon mengatakan konsep partisipasi masyarakat berkaitan dengan konsep keterbukaan. Dalam artian, tanpa keterbukaan pemerintahan tidak mungkin masyarakat dapat melakukan peran-serta dalam kegiatan-kegiatan pemerintahan. ${ }^{5}$ Secara etimologis partisipasi berasal dari Bahasa Inggris kata 'participation' yang artinya pengambilan bagian. Menurut bahasa

\footnotetext{
${ }^{2}$ Erwan Agus Purwanto, Pelayanan Publik Partisipatif, dalam Agus Dwiyanto, 2006. Mewujudkan Good Governance Melalui Pelayanan Publik. Yogyakarta; Gajah Mada University Press. hlm 192

${ }^{3}$ Ibid

${ }^{4}$ Sri Soemantri M., 1992, Bunga Rampai Hukum Tata Negara Indonesia, Bandung: Alumni. hlm 29

${ }^{5}$ Philipus M. Hadjon, 1997. Keterbukaan Pemerintahan dalam Mewujudkan Pemerintahan yang Demokratis, Pidato, diucapkan dalam Lustrum III Ubhara Surya. hlm 4 -5
} 
Belanda disebut 'participatie' yang artinya penyertaan. Bahasa Indonesia kemudian menerjemahkan Partisipasi sebagai perihal turut berperan serta dalam suatu kegiatan. Dengan demikian ada dua hal pokok dalam partisipasi yakni mengambil bagian dan penyertaan atau berperanserta.

Partisipasi berarti memberikan hak kepada masyarakat untuk memberi masukan dalam pembentukan Perda, tanpa secara bersamaan mewajibkan Pemda dan DPRD mempermudah masukan tersebut sampai pada mereka. ${ }^{6}$ Partisipasi bisa bersifat transitif atau intrasitif, bisa pula bermoral atau tak bermoral, juga bisa bersifat dipaksa atau bebas, dan bisa pula bersifat manipulatif maupun spontan. ${ }^{7}$ Pemberlakuan otonomi daerah, ${ }^{8}$ secara normatif, merupakan peluang membuka ruang partisipasi masyarakat dalam proses penyusunan dan implementasi kebijakan. Secara konseptual partisipasi merupakan implementasi dari sistem pemerintahan demokrasi dari rakyat oleh rakyat dan untuk rakyat. $^{9}$

Sebagaimana dijabarkan disebutkan dalam Undang-Undang No. 32 Tahun 2004 tentang Pemerintahan Daerah bahwa penyelenggaraan pemerintahan daerah sesuai dengan amanat Undang-Undang Dasar 1945, pemerintahan daerah mengatur dan mengurus sendiri urusan pemerintahan menurut asas otonomi

\footnotetext{
${ }^{6}$ R. Siti Zuhro, Lilis Mulyani, Fitria, 2010. Kisruh Peraturan Daerah: Mengurai Masalah dan Solusinya. Yogyakarta: Penerbit Ombak. hlm 51

${ }^{7}$ Khairul Muluk, 2006. Desentralisasi dan Pemerintahan Daerah. Jakarta: Penerbit Bayumedia. hlm. 43.

${ }^{8}$ Lihat Pasal 1 ayat (5) UU No. 32 Tahun 2004.

${ }^{9}$ http://id.wikipedia.org/wiki/Demokrasi, diunduh tanggal 6 oktober 2011
}

dan tugas pembantuan, diarahkan mempercepat terwujudnya kesejahteraan masyarakat melalui peningkatan, pelayanan, pemberdayaan, dan peran serta masyarakat, serta peningkatan daya saing daerah dengan memperhatikan prinsip demokrasi, pemerataan, keadilan, keistimewaan dan kekhususan suatu daerah dalam sistem Negara Kesatuan Republik Indonesia.

Ketentuan yuridis mengenai partisipasi masyarakat sebelumnya diatur dalam Undang-Undang No. 10 Tahun 2004 namun kembali ditegaskan dalam Undang-Undang No. 12 Tahun $2011^{10}$ yaitu: (1) Masyarakat berhak memberikan masukan secara lisan dan/atau tertulis dalam Pembentukan Peraturan Perundang-undangan. (2) Masukan secara lisan dan/atau tertulis sebagaimana dimaksud pada ayat (1) dapat dilakukan melalui: a) Rapat dengar pendapat umum; b) Kunjungan kerja; c) Sosialisasi; dan/atau d) Seminar, lokakarya, dan/atau diskusi. Pasal 139 ayat (1) Undang-Undang No. 32 Tahun 2004, mengatakan masyarakat berhak memberikan masukan secara lisan atau tertulis dalam rangka penyiapan atau pembahasan rancangan Peraturan Daerah. ${ }^{11}$

Dengan adanya pengaturan tersebut pemerintah, pemerintah daerah provinsi, kabupaten dan kota dalam pembentukan peraturan perundang-undangan memberikan hak partisipasi terlebih dahulu kepada masyarakat untuk menyampaikan gagasannya melalui mekanisme hukum yang telah

\footnotetext{
${ }^{10}$ Pasal 96 Undang-Undang No. 12 Tahun 2011 tentang Pembentukan Peraturan Perundang Undangan

${ }^{11}$ Undang-Undang No. 32 Tahun 2004 op cit
} 
ditentukan. Selaras dengan pemikiran tersebut Bernadinus Steni, ${ }^{12}$ mengatakan Partisipasi masyarakat dilaksanakan di era otonomi daerah karena dua alasan yaitu: pertama, amanat konstitusi, dan kedua, pelaksanaan kewenangan mengatur dan mengurus oleh pemerintah daerah. Pelaksanaan partisipasi masyarakat dalam era desentralisasi sebetulnya merupakan partisipasi yang given (diberikan). Meskipun demikian, dalam konteks sejarah ketatanegaraan, partisipasi sekarang merupakan pembaharuan atas praktik sentralisasi di masa lalu.

Tujuan dasar peran serta masyarakat adalah mengahasilkan masukan dan persepsi yang berguna dari warganegara dan masyarakat yang berkepentingan (public interest) dalam rangka meningkatkan kualitas pengambilan keputusan, karena dengan melibatkan masyarakat yang berpotensi terkena dampak kebijakan dan kelompok kepentingan (interest groups), para pengambil keputusan dapat menangkap pandangan, kebutuhan dan pengharapan dari masyarakat dan kelompok tersebut, untuk kemudian menuangkan kedalam konsep. $^{13}$ Partisipasi masyarakat juga merupakan pemenuhan terhadap etika politik yang menempatkan rakyat sebagai sumber kekuasaan dan kedaulatan. ${ }^{14}$ Satjipto Rahardjo mengusulkan untuk menjaga netralitas suatu hukum, perlu adanya transparansi dan partisipasi (lebih besar) dalam

\footnotetext{
${ }^{12}$ Bernadinus Steni, 2004. Desentralisasi, Koordinasi dan Partisipasi Masyarakat dalam Pengelolaan Sumberdaya Alam Pasca Otonomi Daerah dalam http://www.huma.or.id. hlm 13

${ }^{13}$ Mahendra Putra Kurnia, dkk. 2007, Pedoman Naskah Akademik Perda Partisipatif. Yogyakarta: Kreasia Total Media (KTM). hlm 41$$
{ }^{14} \text { Ibid }
$$

pembuatan hukum. Kedua hal tersebut kemudian diangkat sebagai asas dalam pembuatan hukum untuk kemudian dilakukan elaborasi lebih lanjut kedalam prosedur dan mekanismenya. ${ }^{15}$ Akhirnya peran partisipasi semakin penting dalam proses pengambilan keputusan setelah dikampanyekan good govenrnance oleh Bank Dunia. Karakteristik good governance atau tata kelola pemerintahan yang baik atau kepemerintahan yang baik adalah partisipasi. ${ }^{16}$ Partsipasi di bangun dibangun atas dasar kebebasan bersosialisasi dan berbicara serta berpartisipasi secara konstruktif. $^{17}$

Di era otonomi daerah, partisipasi masyarakat, perencanaan dari bawah dan kemitraan, anggaran yang pro-poor dan peka jender serta tata kelola pemerintahan yang baik menjadi prinsip-prinsip utama yang mempengaruhi warna pembangunan daerah. Dalam perihal ini, semua pihak duduk bersama sebagai mitra pembangunan daerah yang berkelanjutan. Sehingga permasalahan tarik-ulur dalam hal perencanaan dan realisasi kebijakan antara pemerintah dan pemangku kepentingan dapat di lokalisir dan terselesaikan.

Pemerintah dan pemimpin daerah akan dinilai baik apabila mampu merangkul semua pemangku kepentingan. Untuk itu aparat pemerintahan diharapkan dapat

\footnotetext{
${ }^{15}$ Satjipto Rahardjo, 1998. Mencari Model Ideal Penyusunan Undang-Undanh yang Demokratis (Kajian Sosiologis). Makalah Disampaikan dalam Seminar Nasional Mencari Model Ideal Penyusunan Undang-Undang yang Demokratis dan Kongres Asosiasi Sosiologi Hukum Indonesia. Semarang 15 - 16 April 1998. ${ }^{16}$ Jazim Hamidi, Kemilau Mutik, 2011. Legislatif Drafting; Seri Naskah Akademik Pembentukan Perda. Yogyakarta; Total Media. hlm 54 ${ }^{17}$ Ibid
} 
menghilangkan stigma atau anggapan bahwa LSM itu bukan mitra pemerintah akibat prilaku LSM yang sering berkonfrontasi dengan pemerintahan. Dari pengamatan, sekarang berbagai macam lembaga LSM pun telah belajar menjadi lebih santun dan beretika dalam menyampaikan kritik, masukan dan advokasinya sehingga dapat lebih diterima oleh pemerintah dan publik. Tidak jarang dalam pertemuanpertemuan regional atau internasional LSM juga diminta manjadi advisor atau anggota delegasi oleh pemerintah. Masyarakat sipil, dalam hal ini diwakili oleh LSM, juga belajar terus bagaimana dan di mana bisa berperan di dalam sistem. Beberapa LSM advokasi memilih bentuk kemitraan critical engagement, beberapa memilih constructive engagement.

Menurut Philip J. Eldridge, LSM memiliki 3 (tiga) peran pokok yaitu; memberdayakan masyarakat dalam membentuk organisasinya sendiri sesuai dengan kebutuhannya, mewujudkan nilai-nilai dan melakukan pendekatan partisipatoris dalam pengembangan masyarakat dan peran ketiga adalah menjadi wakil masyarakat dalam memperjuangkan kepentingan kepentingannya (advokasi). Peran LSM sebagai penyeimbang Pemerintah diekspresikan dalam bentuk masukan-masukan dan pengingat tentang hal-hal yang berkaitan dengan hak dan manfaat pembangunan bagi masyarakat terutama kelompok marjinal. LSM seringkali berperan sebagai penyambung informasi isu-isu global, regional dan nasional kepada para pemangku kepentingan di daerah.

Isu-isu panas terkait pemanasan global, perjanjianperjanjian dan kesepakatankesepakatan internasional perlu disampaikan pada pemangku kepentingan di daerah agar konteks inisiatif lokal untuk kepentingan global dapat dihargai dan diperhitungkan. Misalnya dalam isu pencapaian MDGs dan perdagangan karbon, pemangku kepentingan di daerah perlu tahu di mana perannya dan apa kontribusinya dalam peta global itu. Atas hal itu, LSM berperan sebagai penyambung, pendamping dan pemandu agar eforia reformasi dan partisipasi masyarakat tidak disalahgunakan. Dari peran-peran LSM dalam proses pembangunan tersebut terciptalah kemitraan yang saling mengisi satu sama lain. Misalnya bersama-sama menterjemahkan konsep perencanaan dari bawah, multi pihak dan akuntabel secara berkelanjutan.

1. Fungsi LSM menurut Pasal 5 UU No. 8 Tahun 1985 adalah :

a. Wadah penyalur kegiatan sesuai kepentingan anggotanya;

b. Wadah pembinaan dan pengembangan anggotanya dalam usaha mewujudkan tujuan organisasi:

c. Wadah peranserta dalam usaha menyukseskan pembangunan nasional;

d. Sarana penyalur aspirasi anggota, dan sebagai sarana komunikasi sosial timbal balik antar anggota dan/atau antar Organisasi Kemasyarakatan, dan antara Organisasi Kemasyarakatan dengan organisasi kekuatan 
sosial politik, Badan Permusyawaratan/

Perwakilan Rakyat, dan Pemerintah.

\section{Pola Kerja LSM}

Sesuai dengan fungsi LSM dalam UU No. 8 Tahun 1985 maka secara garis besar ada 2 (dua) pola dan pendekatan yang dapat dilakukan LSM dalam merealisasikan visi dan misinya yakni: advokasi dan intervensi.

\subsection{Advokasi}

Pola ini biasanya dilakukan oleh LSM garis keras yang lebih memfokuskan kegiatannya pada perubahan kebijakan pemerintah. LSM bidang advokasi lebih banyak berkiprah dengan menggunakan pendekatan hukum dan politik. Misalnya LSM memantau transparansi penggunaan APBD dan Penegakan Hukum.

\subsection{Intervensi}

LSM intervensi lebih banyak memfokuskan dalam kegiatan praktis. Misalnya LSM yang bergerak dalam hal pengembangan ekonomi, teknologi tepat guna dan sebagainya

Dari kedua pola pendekatan yang dilakukan LSM dengan medudukkan peran pemerintah dan LSM maka semangat yang dapat dibangun adalah Kemitraan. Dengan kemitraan biasanya aturan pembagian peran dan tanggung jawab dapat terlihat. Dimana porsiporsi kegiatan dan fungsi yang tidak dapat dilakukan pemerintah dapat diisi oleh LSM begitu pula sebaliknya.

Ada beberapa kelebihan dan kekurangan pola kemitraan antar pemerintah maupun LSM. Kelebihan kemitraan antara Pemerintah dan LSM antara lain:

Bagi Pemerintah:

- Sinergi semua pemangku kepentingan dapat mempercepat pencapaian tujuan.

- Hal-hal yang terkait dengan pendekatan kepada masyarakat di lapangan dapat dijembatani oleh LSM sehingga mempermudah komunikasi dan koordinasi pelaksanaan program/ kegiatan

- Mendapat masukan melalui pola konsultasi yang konstruktif.

\section{Bagi LSM}

- Misi advokasi kebijakan dapat lebih mudah didiskusikan dan didorongkan

- Isu keadilan social dapat diterjemahkan lebih cepat ke dalam program arus utama pembangunan.

- Komunikasi dua arah memungkinkan inisiatif datang dari LSM

Sedangkan kekurangan atau kelemahan kemitraan antara lain: Bagi Pemerintah
komunikasi menjadi agak
kompleks karena lebih banyak pertimbangan dan banyak pihak yang terlibat
- $\quad$ Beberapa proses
kegiatan dapat memerlukan penyesuaian dengan tata administrasi dan penganggaran 
yang ada

Bagi LSM :

$\bullet$

Tingkat kekritisan dapat melemah atau berkurang karena konsentrasi lebih banyak diarahkan pada pemikiran bersama semua pihak.

- $\quad$ Pergantian atau

rotasi pejabat seringkali memperlambat proses kemitraan

\section{Bentuk Kerjasama LSM dan Pemerintah}

Memperhatikan fungsi Ormas sesuai UU No. 8 Tahun 1985, paling tidak ada empat peranan yang dapat dimainkan oleh LSM di era pemerintahan daerah, menurut Andra L. Corrothers dan Estie W. Suryatna peranan yang dijalankan yaitu: katalisasi perubahan system, memonitor pelaksanaan system dan penyelenggaraan Negara, memfasilitasi rekonsiliasi warga dengan lembaga peradilan dan yang terakhir adalah implementasi program pelayanan. ${ }^{18}$ Katalisasi perubahan system dapat dilakukan dengan mengangkat sejumlah masalah penting dalam masyarakat dan melakukan advokasi demi perubahan kebijakan pemerintah. Sedangkan implementasi program pelayanan dilakukan melalui sejumlah pelaksanaan kegiatan dan program dibidang pendidikan dan kesehatan serta proyek-proyek pemberdayaan masyarakat.

Adapun bentuk hubungan kerjasama antara Pemerintah dan

\footnotetext{
${ }^{18}$ Affan Gafar, 2006. Politik Indonesia, Transisi Menuju Demokrasi, Pustaka Pelajar, Yogyakarta. Hal 205
}

LSM adalah:

1. Hubungan yang bersifat collaboration/cooperation, dalam konteks hubungan seperti ini pemerintah menganggap bahwa bekerja sama dengan kalangan LSM merupakan sesuatu yang menguntungkan. LSM dan pemerintah berdiri pada posisi yang equal dan sejajar. Hubungan ini umumnya dilaksanakan oleh LSM-LSM dengan ruang lingkup kegiatan bidang pemberdayaan masyarakat. Wujud kerjasama antara LSM dan pemerintah antara lain dalam bentuk pelatihan, sosialisasi, seminar dan dan kegiatan lain yang sifatnya meningkatkan kapasitas masyarakat. Contohnya kegiatan workshop bidang pendidikan anak yang dilakasanakan kerjasama antara LSM dan Dinas Pendidikan. Contoh lain kerjasama dalam program Gerakan Nasional Rehabilitasi Lahan (GNRHL). Dalam pola hubungan ini, pada praktiknya LSM melaksanakan program dan proyek-proyek pemerintah. Pemerintah menyediakan dana sedangkan LSM membantu dengan keahlian mereka. Namun, kebanyakan LSM jenis ini memiliki ketergantungan terhadap pemerintah terutama dari segi financial dan pendanaan program.

2. Model hubungan yang bersifat containment/sabotage/

dissolution, dimana pemerintah melihat LSM sebagai tantangan, bahkan ancaman. Pemerintah dapat mengambil langkah tertentu untuk membatasi ruang 
gerak LSM. Contoh kasus Antasari Azhar. Dalam pandangan ini antara LSM dan pemerintah merupakan pihak yang harus diawasi dan ditekan karena banyak melakukan manipulasi yang merugikan masyarakat. LSM sebagai kelompok yang menyuarakan kepentingan masyarakat merasa perlu membela rakyat untuk mendapatkan hak-haknya. Hubungan antara LSM dan pemerintah adalah hubungan yang bersifat politis, LSM mengambil peran sebagai kelompok yang kritis dan mempertentangkan kepentingan rakyat dengan ketiakadilan dari pemerintah. Karakter dari LSM-LSM kritis ini adalah menggunakan kritik legitimasi sebagai alat untuk menekan pemerintah. $^{19}$

\section{Penutup}

1. Guna memperkuat civil society di Kota Bandar Lampung, diperlukan adanya organisasi sosial yang mandiri. Diantara organisasi sosial dan politik yang memiliki tingkat kemandirian yang tinggi dari lembaga swadaya masyarakat. Karakteristik LSM yang bercirikan: mandiri dan tidak menggantungkan diri pada bantuan pemerintah dalam hal finansial, non-partisan, tidak mencari keuntungan ekonomi, bersifat sukarela, dan bersendi

${ }^{19}$ Anwari WMK (editor), dan Maruto MD, 2002, Kumpulan Tulisan Reformasi Politik dan Kekuatan Masyarakat, LP3ES, Jakarta. Hal. 182183 pada gerakan moral, menjadikan LSM dapat bergerak secara luwes tanpa dibatasi oleh ikatan-ikatan motif politik dan ekonomi. Peran LSM dalam civil society diperlukan terutama dalam rangka peningkatan kapasitas dan pemberdayaan masyarakat ditingkat akar rumput. Kedudukan birokrasi pemerintah bertindak sebagai fasilitator, motivator, dan dinamisator terhadap LSM.

2. Hubungan LSM dengan Pemerintah memilik dua model hubungan antara LSM di Kota Bandar Lampung. Pertama adalah hubungan yang bersifat collaboration/cooperation, yakni pemerintah menganggap bahwa bekerja sama dengan kalangan LSM merupakan sesuatu yang menguntungkan. LSM dan pemerintah berdiri pada posisi yang equal dan sejajar. Hubungan kegiatan di bidang pemberdayaan masyarakat. Kedua adalah hubungan yang bersifat containment/sabotage /dissolution, dimana pemerintah melihat LSM sebagai tantangan, bahkan ancaman. Hubungan antara LSM dan pemerintah merupakan hubungan yang bersifat politis, LSM mengambil peran sebagai kelompok yang kritis dan mempertentangkan kepentingan rakyat dengan ketidakadilan dari pemerintah.

\section{Daftar Pustaka}

Affan Gafar, 2006. Politik Indonesia, Transisi Menuju Demokrasi, Pustaka Pelajar, Yogyakarta.

Anwari WMK (editor), dan Maruto MD, 2002, 
Kumpulan Tulisan Reformasi

Politik dan Kekuatan

Masyarakat, LP3ES, Jakarta.

Bernadinus Steni, 2004.

Desentralisasi, Koordinasi dan

Partisipasi Masyarakat dalam

Pengelolaan Sumberdaya Alam

Pasca Otonomi Daerah dalam

http://www.huma.or.id.

Erwan Agus Purwanto, Pelayanan

Publik Partisipatif, dalam

Agus Dwiyanto, 2006.

Mewujudkan Good

Governance Melalui

Pelayanan Publik. Yogyakarta;

Gajah Mada University Press

Jazim Hamidi, Kemilau Mutik, 2011.

Legislatif Drafting; Seri

Naskah Akademik

Pembentukan Perda.

Yogyakarta; Total Media.

Khairul Muluk, 2006. Desentralisasi dan Pemerintahan Daerah. Jakarta: Penerbit Bayumedia.

Kompas 13 Januari 2003 dalam NGO ditengah Kepungan

Kepentingan Global, http://lafadl.wordpress.com/20 06/07/15/ngo-di-tengahkepungan-kepentingan-global/.

Mahendra Putra Kurnia, dkk. 2007, Pedoman Naskah Akademik Perda Partisipatif.

Yogyakarta: Kreasia Total Media (KTM).

Philipus M. Hadjon, 1997.

Keterbukaan Pemerintahan dalam Mewujudkan

Pemerintahan yang

Demokratis, Pidato, diucapkan dalam Lustrum III Ubhara

Surya.

R. Siti Zuhro, Lilis Mulyani, Fitria, 2010. Kisruh Peraturan

Daerah: Mengurai Masalah dan Solusinya. Yogyakarta: Penerbit Ombak.
Satjipto Rahardjo, 1998. Mencari

Model Ideal Penyusunan

Undang-Undanh yang

Demokratis (Kajian

Sosiologis). Makalah

Disampaikan dalam Seminar

Nasional Mencari Model Ideal

Penyusunan Undang-Undang

yang Demokratis dan Kongres

Asosiasi Sosiologi Hukum

Indonesia. Semarang $15-16$

April 1998.

Sri Soemantri M., 1992, Bunga

Rampai Hukum Tata Negara

Indonesia, Bandung: Alumni.

Undang-Undang No. 12 Tahun 2011

tentang Pembentukan

Peraturan Perundang -

Undangan

Undang-Undang No. 32 Tahun 2004 tentang Pemerintahan Daerah. http://id.wikipedia.org/wiki/De mokrasi, diunduh tanggal 6 oktober 2011. 